\title{
Amino acid profile of raw and locally processed seeds of Prosopis africana and Ricinus communis: potential antidotes to protein malnutrition
}

\author{
Chidi U. Igwe ${ }^{1 *}$, Okey A. Ojiako ${ }^{1}$, Ken C. Anugweje ${ }^{2}$, Linus A. Nwaogu' ${ }^{1}$, and \\ Cosmas O. Ujowundu ${ }^{1}$
}

${ }^{1}$ Department of Biochemistry, Federal University of Technology, Owerri, Nigeria; ${ }^{2}$ Department of Health Services, University of Port Harcourt, Port Harcourt, Nigeria.

*Corresponding Author: Chidi U. Igwe, Department of Biochemistry, Federal University of Technology, Owerri, Nigeria.

Submission date: March 21, 2012, Acceptance date: April 20, 2012; Publication date: April 22, 2012

\begin{abstract}
Background: Increasing incidence of malnutrition occasioned by high incidence of hunger, worsening food situation in the world, insufficient availability and high cost of animal protein sources, has necessitated extensive research into and use of alternative plant protein sources especially underexploited leguminous seeds.
\end{abstract}

Methods: Flours from raw, boiled and fermented seeds of Prosopis africana and Ricinus communis were evaluated for crude protein and amino acid (AA) profiles, and their protein qualities determined.

Results: Fermentation improved the protein contents of raw seeds of $P$. africana and $R$. communis by $18.70 \%$ and $3.95 \%$ respectively. In the raw and fermented $P$. africana seeds, glutamate at $132.60 \pm 1.30$ and $182.70 \pm 3.02 \mathrm{mg} / \mathrm{g}$ crude protein $(\mathrm{mg} / \mathrm{gcp})$ was the most abundant amino acid (AA), while leucine (62.80 \pm 0.60 and $79.50 \pm 2.01 \mathrm{mg} / \mathrm{gcp})$ was the most concentrated essential amino acid (EAA). Aspartate $(151.90 \pm 2.01$ and $170.10 \pm 2.00 \mathrm{mg} / \mathrm{gcp})$ and arginine $(72.80 \pm 2.01$ and $78.60 \pm 2.00 \mathrm{mg} / \mathrm{gcp})$ were the most concentrated and abundant non-essential amino acid (NEAA) and EAA in the raw and fermented samples of $R$. communis respectively. The total AA concentrations $(\mathrm{mg} / \mathrm{gcp}$ ) of raw and fermented $P$. africana were 733.00 and 962.60 respectively, while those of $R$. communis were 823.50 and 894.10 respectively. The total EAA contents $(\mathrm{mg} / \mathrm{gcp}$ ) for $P$. africana were 311.00 (raw) and 404.50 (fermented), and for $R$. communis; 401.10 (raw) and 430.30 (fermented). Threonine was the limiting EAA in raw and fermented $P$. africana, whereas lysine was the limiting EAA in $R$. communis raw sample. Fermentation significantly $(\mathrm{p}<0.05)$ increased the individual AA compositions of $P$. africana and $R$. communis by $94 \%$ and $53 \%$ respectively, while boiling reduced these parameters significantly $(\mathrm{p}<0.05)$ by $47 \%$ and $82 \%$ respectively. 
Conclusion: $P$. africana and $R$. communis seeds are potentially important plant sources of protein and essential amino acids, and so could be of great importance in combating malnutrition and food security problems generally.

Key words: Amino acid score; condiments; crude protein; fermentation; legumes; nutrition.

\section{INTRODUCTION:}

Malnutrition is directly responsible for over 300,000 deaths per year in developing countries and contributes indirectly to over half the deaths in children worldwide [1]. It is the consequence of a range of factors that are often related to poor food quality, insufficient food intake and severe infectious diseases, or most times, combinations of the three [2]. Protein-energy malnutrition is a direct consequence of poor food quality. It refers to an imbalance between the supply of protein or its metabolic building blocks, amino acids, and the body's demand for them to ensure optimal growth and function. Unfortunately, protein-rich foods are in short supply, and thus not within the reach of low-income households who form the bulk of the population in developing countries [3]. To combat these protein supply problems, current researches have focused on vast numbers of less familiar plant resources existing in the wild [4]. Considering the high incidence of hunger occasioned by the worsening food situation in the world, the insufficient availability and high cost of animal protein sources where available, there is then the need for extensive research into alternative plant protein sources especially underexploited leguminous seeds that are commonly available but largely ignored.

Leguminous seeds are known good sources of plant proteins and are traditionally available but most of their values are rarely appreciated. Among such available but neglected legumes are Prosopis africana and Ricinus communis.

Prosopis africana is a leguminous plant of the Fabaceae family. It is a flowering plant that is locally called "kiriya" in Hausa, "okpehe" in Idoma and "gbaaye" in Tiv languages of Nigeria. It was originally found in the Sahel and Savannah forests of Senegal to Ethiopia. The trees of $P$. africana are common in the middle belt and northern parts of Nigeria [5]. It grows to a height of 4-20 m, with slightly rounded buttress roots and dark stem bark, which is scaly, slash and has white streaks. It flowers once a year. The fruits are smooth, hard pod-like capsules having banana fruit shape and is brown-black in colour. The seeds are many, tiny and very hard, brownish-black in colour with high resistance to water and insect attack. It is traditionally used for formulation of animal feeds and preparation of local condiments through boiling and fermentation processes [5].

Ricinus communis, commonly called Castor bean, is a native plant in Ethiopian region of tropical East Africa, and warm temperate regions of the world. It belongs to the Euphorbiaceae family and has many vernacular names; "ogiri" (i.e. melon) in Igbo and "giga" in Tiv languages of Nigeria, "carapaterior" in Brazil and "galo" in Ethiopia [6]. Castor plant is a robust annual that may grow up to $2.5 \mathrm{~m}$ in one season with full sunlight, heat and adequate moisture. The flowers occur most of the year in dense terminal clusters. The spiny seed pods are made up of three carpel which split apart at maturity, releasing shiny seeds with intricate designs [6]. The seeds 
are extremely poisonous but have numerous economic and medical importance [6,7]. They are used for preparation of traditional condiments [8].

Condiments are substances used to give flavour to food or that is eaten with food. Traditionally, in the area of study, they are made from fermented seeds and are used mostly by the poor as low-cost protein sources in food. It has been reported that fermentation as a process improves flavour and taste, and has been described as a processing method used in homes to improve nutritional quality of foods $[9,10]$. This study will provide data on the protein quality as well as the effects of traditional processing techniques, viz: boiling and fermentation, on these two leguminous seeds, which are hitherto neglected and to the best of our knowledge, have not been properly documented in the study area.

\section{MATERIALS AND METHODS:}

Collection and Preparation of Seed Samples: Apparently healthy seed samples of Prosopis africana and Ricinus communis were purchased from Makurdi Main Market, Benue State, Nigeria. They were identified by a Plant Taxonomist at the Department of Forestry and Wildlife Technology, Federal University of Technology, Owerri, Nigeria, where voucher specimens were deposited.

Each of the seed samples was divided into three portions and processed as follows:

Raw Seed Samples: One portion $(500 \mathrm{~g})$ of each seed sample was dried to a constant weight in an oven (Gallenkamp model III-100) at $60^{\circ} \mathrm{C}$, de-shelled, ground into fine powder using a manual grinder, sieved through a No. 20 mesh sieve and stored in a dry, airtight, labeled glass container in a refrigerator at $4^{0} \mathrm{C}$ prior to analysis.

Boiled Seed Samples: The second portion (500g) of each seed sample was boiled in water at $100^{\circ} \mathrm{C}$ for $12 \mathrm{~h}$ using a gas cooker, de-shelled and ground with a manual grinder into a paste. The paste was dried in the oven at $60^{\circ} \mathrm{C}$ to a constant weight and stored in another set of labeled glass container in a refrigerator at $4^{0} \mathrm{C}$ until analysis.

Fermented Seed Samples: The third portion (500g) of each seed sample was boiled for 12 $\mathrm{h}$ using a gas cooker, de-shelled and ground with a manual grinder into a paste. Each paste was wrapped in a muslin cloth, covered in a pot and allowed to ferment at room temperature $\left(\approx 30^{\circ} \mathrm{C}\right)$ for $72 \mathrm{~h}$. At the end of the fermentation period, each sample was dried in the oven at $60^{\circ} \mathrm{C}$ to a constant weight and stored in an appropriately labeled glass container in a refrigerator at $4^{0} \mathrm{C}$ until analysis.

Determination of Protein and Amino Acid Compositions: The nitrogen content of the three ground seed sample portions was determined by the standard micro-Kjeldahl method, as described by Pearson [11], and the percentage nitrogen obtained was converted to crude protein by multiplying by 6.25 [11].

Initially, $200 \mathrm{mg}$ of each ground seed sample was defatted with chloroform/methanol mixture in a ratio of $1: 1$. Then, $30 \mathrm{mg}$ of the defatted sample was put into a glass ampoule, $7 \mathrm{ml}$ of $6 \mathrm{M} \mathrm{HCl}$ was added and oxygen expelled by passing nitrogen into the ampoule. The sealed ampoule was put in the oven at $105^{\circ} \mathrm{C}$ for $22 \mathrm{~h}$, allowed to cool and filtered. The filtrate was then evaporated to dryness at $40^{\circ} \mathrm{C}$ under vacuum in a rotary evaporator. The residue was dissolved with $5 \mathrm{ml}$ acetate buffer ( $\mathrm{pH} 2.0)$ and loaded into the amino acid analyzer where the amino acid 
compositions of the seed samples were determined by Ion Exchange Chromatographic (IEC) method using the Technicon Sequential Multisample Amino Acid Analyzer (Technicon Instruments Corporation, New York).

Estimation of Seed Samples Protein Quality: To estimate the quality of dietary protein in the seed samples, the Total Essential Amino Acid (TEAA), Total Non-Essential Amino Acid (TNEAA), Total Sulphur Amino Acid (TSAA), percentage of cystine in TSAA (\%Cys/TSAA), Total Aromatic Amino Acid (TArAA), Leu/Ile ratio, etc, were calculated as earlier described [12]. The Predicted Protein Efficiency Ratio (P-PER) was also determined using the equation of Alsmeyer et al,.[13] i.e. P-PER $=-0.468+0.454$ (Leu) -0.105 (Tyr). The essential amino acid scores of the seed samples were also calculated using the formula: Amino acid score = amount of amino acid per test protein $(\mathrm{mg} / \mathrm{g}) /$ amount of amino acid per protein in reference pattern $(\mathrm{mg} / \mathrm{g})$ [12].

Statistical Analysis: Data generated were organized into means and standard deviations. Their coefficient of variations in percentages were calculated. Inferences were taken at confidence level of $95 \%$ using one-way analysis of variance and Tukey posthoc tests [14], with the aid of a computer-based statistical package, GraphPad Prism 5.3 (GraphPad Software Inc. USA).

\section{RESULTS AND DISCUSSION:}

The crude protein contents of the raw, boiled, and boiled + fermented (simply represented as fermented) seed samples of Prosopis africana and Ricinus communis are shown in Figure 1.

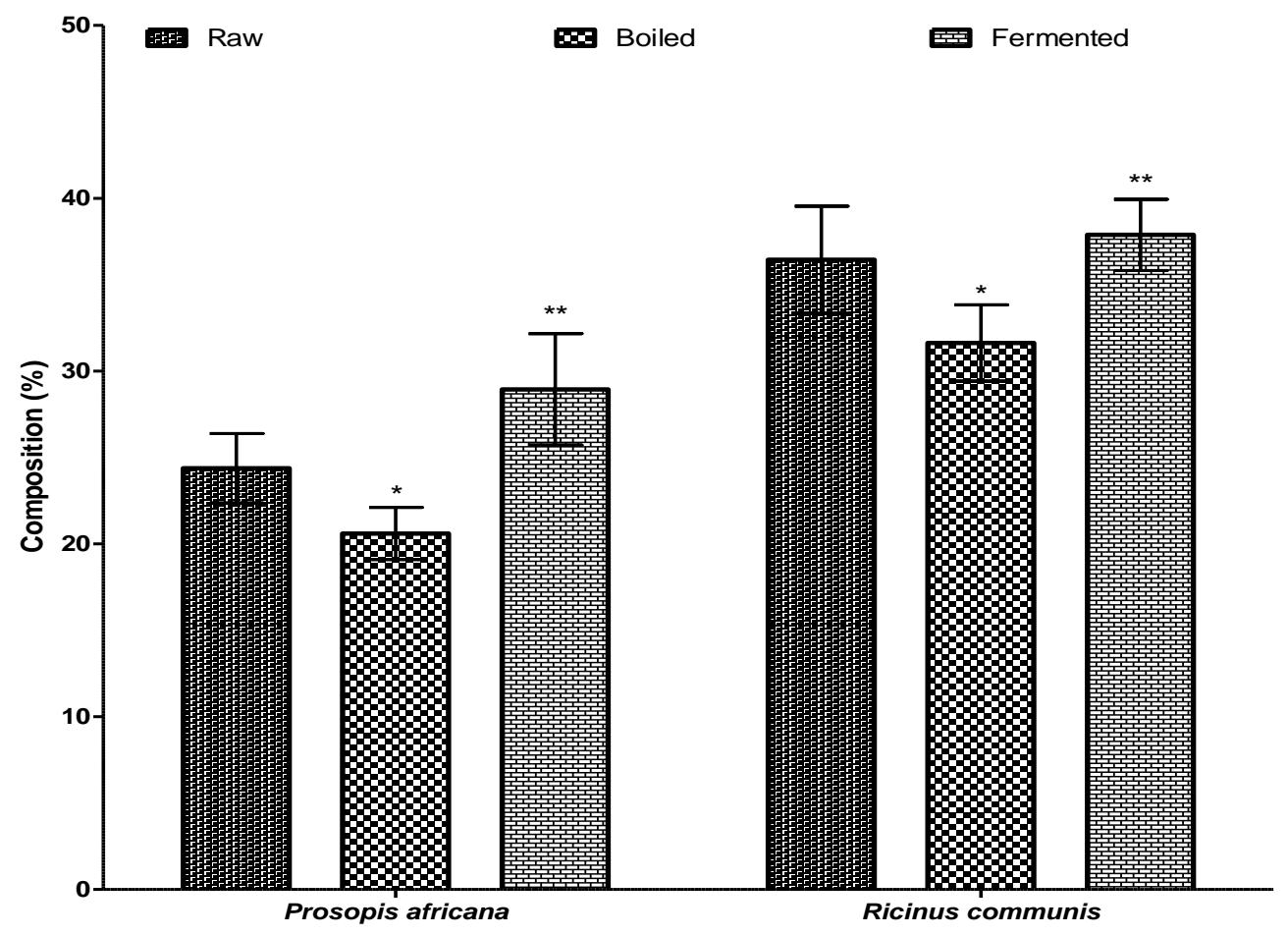

Figure 1: Crude protein composition (\%) of raw, boiled and fermented seed samples of Prosopis africana and Ricinus communis. $*$ (or $* *)=$ Value significantly $(\mathrm{p}<0.05)$ reduced (or increased) in comparison with respective raw sample value. 
It shows that the crude protein content of the raw seeds were $24.38 \pm 2.01 \mathrm{~g} / 100 \mathrm{~g}$ and $36.44 \pm$ $3.10 \mathrm{~g} / 100 \mathrm{~g}$ respectively. Boiling, as a processing technique significantly $(\mathrm{p}<0.05)$ reduced the seeds' crude protein content by $15.50 \%$ and $13.20 \%$ respectively, while the combined processes of boiling and fermentation significantly $(\mathrm{p}<0.05)$ increased it by $18.70 \%$ and $3.95 \%$ respectively. These observations are in consonance with earlier reported raw seed crude protein levels of $25.74 \%$ and $23.6 \%$ in P. africana [15,5], and $21-48 \%$ in $R$. communis [16]. Generally, the crude protein levels obtained in this present study are comparable to those of Sesamum indicum (24.74 $\pm 0.56 \%$ ), fluted pumpkin (28.7\%) and African oil bean (36.2\%) seeds [17,18], but higher than those of several reported common seeds and fruits [4,19]. Boiling and fermentation have been previously reported to have contrasting effects on protein contents of food materials. While boiling reduces crude protein content, fermentation was reported to improve nutritional quality [4,20]. The positive effect of fermentation is associated with the action of microflora and enzymes which breakdown complexes enhancing release and availability of proteins. On the other hand, the reduction in protein content associated with boiling for up to $12 \mathrm{~h}$ in this study may be due to the heat involved which leads to Maillard reactions and subsequent Amadori rearrangements making the protein and its amino acids significantly unavailable [21].

The amino acid compositions of the raw, boiled and fermented seed samples of $P$. africana and $R$. communis are presented in Tables 1 and 2 . The amino acid concentrations of the two seed crops were variously distributed amongst the three samples (i.e. raw, boiled and fermented) of each crop, and these are apparent from results of the various samples and in their coefficient of variation percentages (CV\%). Glutamic acid (Glu) at 132.60, 131.50 and $182.70 \mathrm{mg} / \mathrm{g}$ crude protein $(\mathrm{mg} / \mathrm{gcp})$ was the most concentrated amino acid amongst the three samples of $P$. africana, while aspartic acid (Asp) at 151.90, 141.90 and $170.10 \mathrm{mg} / \mathrm{gcp}$ was the most concentrated amino acid in the respective samples of $R$. communis. In both seed crops, the remaining acidic amino acid in each case, occupied the second position in terms of abundance.

These observations corroborated earlier reported trends of Glu and Asp being the most concentrated amino acids in some oil seeds [22], Cola acuminate, Garcinia kola and Anacardium occidentale [23] and some legumes even after different processing techniques [24] as well as raw P. africana [5]. Methionine (Met) was the least concentrated in the three samples of $P$. africana at $10.40,4.20$ and $13.10 \mathrm{mg} / \mathrm{gcp}$ respectively, while glycine (Gly) was the least concentrated in $R$. communis with values of $10.80,4.00$ and $16.8 \mathrm{mg} / \mathrm{gcp}$ respectively. The observed low concentration of Met in these legume sample is in consonance with earlier reported least concentration of Met in some raw and processed legumes [24, 25]. As can be seen from Figure 1, $R$. communis has higher crude protein content than $P$. africana. Similarly, raw seeds of $R$. communis were richer (11 amino acids out of $17 ; 64.71 \%$ ) than $P$. africana in the following amino acids; Lys, His, Arg, Thr, Val, Met, Ile, Leu, Phe, Asp and Ala. However, fermentation changed the trend making fermented $P$. africana to be apparently richer (12 amino acids out of $17 ; 70.58 \%$ ) than fermented $R$. communis in all non-essential amino acids (except Asp) as well as Phe, Leu, Ile, Val and His. Whereas fermentation significantly $(\mathrm{p}<0.05)$ increased amino acid compositions of the fermented seed sample of $P$. africana by $94.12 \%$, it only, but significantly ( $<<0.05$ ), improved the amino acid compositions of $R$. communis by $52.94 \%$ over their respective raw samples. 
Table 1: Amino acid profiles (g/100g crude protein) of raw, boiled and fermented seed samples of Prosopis africana

\begin{tabular}{|c|c|c|c|c|c|c|}
\hline Amino acids & Raw & Boiled & Fermented & Mean & SD & CV\% \\
\hline \multicolumn{7}{|c|}{ Essential amino acids } \\
\hline Lys & $40.60 \pm 1.10^{\mathrm{a}}$ & $34.60 \pm 0.80^{\mathrm{b}}$ & $47.20 \pm 0.30^{c}$ & 40.80 & 6.30 & 15.45 \\
\hline His & $16.30 \pm 0.30^{\mathrm{a}}$ & $11.90 \pm 0.10^{\mathrm{b}}$ & $25.00 \pm 0.10^{c}$ & 17.73 & 6.67 & 37.59 \\
\hline Arg & $41.60 \pm 1.00^{\mathrm{a}}$ & $30.00 \pm 0.50^{\mathrm{b}}$ & $49.00 \pm 0.51^{\mathrm{c}}$ & 40.20 & 9.58 & 23.82 \\
\hline Thr & $24.60 \pm 0.61^{\mathrm{a}}$ & $23.60 \pm 0.20^{\mathrm{a}}$ & $27.71 \pm 0.10^{\mathrm{b}}$ & 24.63 & 3.05 & 12.38 \\
\hline Val & $40.30 \pm 0.80^{\mathrm{a}}$ & $38.20 \pm 0.31^{\mathrm{a}}$ & $53.20 \pm 0.60^{\mathrm{b}}$ & 43.90 & 8.12 & 18.50 \\
\hline Met & $10.40 \pm 0.10^{\mathrm{a}}$ & $4.20 \pm 0.10^{\mathrm{b}}$ & $13.10 \pm 0.20^{c}$ & 9.23 & 4.56 & 49.42 \\
\hline Ile & $32.80 \pm 1.22$ & $25.20 \pm 0.21^{b}$ & $42.60 \pm 0.61^{\mathrm{c}}$ & 33.53 & 8.72 & 26.01 \\
\hline Leu & $62.80 \pm 0.60^{\mathrm{a}}$ & $60.40 \pm 0.81^{\mathrm{a}}$ & $79.50 \pm 2.00^{\mathrm{b}}$ & 67.57 & 10.40 & 15.40 \\
\hline Phe & $41.60 \pm 3.01^{\mathrm{a}}$ & $40.60 \pm 0.21^{\mathrm{a}}$ & $67.20 \pm 1.21^{\mathrm{b}}$ & 49.80 & 15.08 & 30.28 \\
\hline \multicolumn{7}{|c|}{ Non-essential amino acids } \\
\hline Glu & $132.60 \pm 1.30^{\mathrm{a}}$ & $131.50 \pm 1.01^{\mathrm{a}}$ & $182.70 \pm 3.02^{\mathrm{b}}$ & 148.90 & 29.25 & 19.64 \\
\hline Ser & $46.80 \pm 0.60^{\mathrm{a}}$ & $45.90 \pm 0.59^{\mathrm{a}}$ & $64.40 \pm 1.01^{\mathrm{b}}$ & 52.37 & 10.43 & 19.92 \\
\hline Asp & $66.80 \pm 1.20^{\mathrm{a}}$ & $51.20 \pm 0.41^{\mathrm{a}}$ & $81.30 \pm 1.03^{\mathrm{a}}$ & 66.43 & 15.05 & 22.66 \\
\hline Pro & $38.00 \pm 0.31^{\mathrm{a}}$ & $36.10 \pm 0.20^{\mathrm{b}}$ & $41.90 \pm 0.50^{c}$ & 38.67 & 2.96 & 7.65 \\
\hline Gly & $33.50 \pm 0.91^{\mathrm{a}}$ & $30.10 \pm 0.12^{b}$ & $46.00 \pm 0.42^{c}$ & 36.53 & 8.37 & 22.92 \\
\hline Ala & $49.70 \pm 0.60^{\mathrm{a}}$ & $23.20 \pm 0.21^{\mathrm{b}}$ & $59.30 \pm 0.91^{\mathrm{c}}$ & 44.07 & 18.70 & 42.43 \\
\hline Cys & $21.20 \pm 0.21^{\mathrm{a}}$ & $20.50 \pm 0.11^{\mathrm{a}}$ & $41.90 \pm 0.20^{\mathrm{b}}$ & 27.87 & 12.16 & 43.63 \\
\hline Tyr & $33.40 \pm 0.30^{\mathrm{a}}$ & $32.20 \pm 0.23^{\mathrm{a}}$ & $40.60 \pm 0.51^{\mathrm{b}}$ & 35.40 & 4.54 & 12.83 \\
\hline
\end{tabular}

Values (mean \pm standard of duplicate determinations) with different superscripts per row are significantly $(p<0.05)$ different. SD, Standard deviation; CV\%, coefficient of variation percentage.

On the other hand, boiling significantly $(\mathrm{p}<0.05)$ reduced the amino acid compositions by $47.06 \%$ in $P$. africana and $82.35 \%$ in $R$. communis. These reductive effects of boiling on protein and amino acid compositions of the seeds, as discussed earlier may be attributed to Amadori rearrangements that may go beyond the deoxy-ketosyl stage. It may also be due to formation of D-amino acids which results from high and prolonged heat treatment [21]. This was the case because, the method usually used for amino acid analysis will only detect L-amino acids from animal and plant proteins that do not produce racemisation [26].

Meanwhile, the higher crude protein contents observed in $R$. communis samples notwithstanding, the combined processes of boiling and fermentation improved amino acid quality of $P$. africana more. This may be attributed, partially to the observed higher reductive $(82.35 \%)$ effect of boiling on the $R$. communis amino acid composition. Boiling being a pre-step before fermentation during local condiments production. Fermentation significantly $(\mathrm{p}<0.05)$ improved all the amino acids except Asp in P. africana, and Arg, Thr, Val, Met, Ile, Leu, Phe and Glu in $R$. communis. The observed significant $(\mathrm{p}<0.05)$ improvement in all essential amino acid compositions of $P$. africana, along with Lys and Met in $R$. communis corroborates earlier observed similar effect of fermentation on Lys, His, Arg, Thr, Val, Ile and Phe contents of cocoa nibs [27]. These observations followed the trend reported for guinea corn, where steeping of the 
grains improved the amino acid profile over the raw and germinated samples in Arg, His, Met, Phe, Thr, Val, Ala, Cys, Gly, Pro, Ser and Tyr [28].

Table 2: Amino acid profiles (g/100g crude protein) of raw, boiled and fermented seed samples of Ricinus communis

\begin{tabular}{|c|c|c|c|c|c|c|}
\hline Amino acids & Raw & Boiled & Fermented & Mean & SD & CV\% \\
\hline \multicolumn{7}{|c|}{ Essential amino acids } \\
\hline Lys & $44.00 \pm 0.20^{\mathrm{a}}$ & $41.30 \pm 0.50^{\mathrm{b}}$ & $52.90 \pm 0.71^{\mathrm{c}}$ & 46.07 & 6.07 & 13.18 \\
\hline His & $16.90 \pm 0.10^{\mathrm{a}}$ & $13.10 \pm 0.10^{\mathrm{b}}$ & $21.30 \pm 0.32^{\mathrm{c}}$ & 17.10 & 4.10 & 24.00 \\
\hline $\operatorname{Arg}$ & $72.80 \pm 2.01^{\mathrm{a}}$ & $53.20 \pm 1.10^{\mathrm{b}}$ & $78.60 \pm 2.00^{\mathrm{a}}$ & 68.20 & 13.31 & 19.52 \\
\hline Thr & $37.20 \pm 0.21^{\mathrm{a}}$ & $36.50 \pm 0.31^{\mathrm{a}}$ & $38.20 \pm 0.12^{\mathrm{a}}$ & 37.30 & 0.85 & 2.29 \\
\hline Val & $48.70 \pm 0.30^{\mathrm{a}}$ & $40.50 \pm 0.12^{b}$ & $50.10 \pm 1.01^{\mathrm{a}}$ & 46.43 & 5.19 & 11.17 \\
\hline Met & $27.60 \pm 0.21^{\mathrm{a}}$ & $23.40 \pm 0.11^{\mathrm{b}}$ & $29.00 \pm 0.21^{\mathrm{a}}$ & 26.67 & 2.91 & 10.93 \\
\hline Ile & $37.00 \pm 0.50^{\mathrm{a}}$ & $26.40 \pm 0.32^{\mathrm{b}}$ & $38.00 \pm 1.03^{\mathrm{a}}$ & 33.80 & 6.43 & 19.02 \\
\hline Leu & $64.50 \pm 2.01^{\mathrm{a}}$ & $60.00 \pm 1.40^{\mathrm{a}}$ & $66.50 \pm 2.33^{\mathrm{a}}$ & 63.67 & 3.33 & 5.23 \\
\hline Phe & $52.40 \pm 1.07^{\mathrm{a}}$ & $43.40 \pm 0.81^{\mathrm{b}}$ & $55.70 \pm 1.21^{\mathrm{a}}$ & 50.50 & 6.37 & 12.61 \\
\hline \multicolumn{7}{|c|}{ Non-essential amino acids } \\
\hline Glu & $102.20 \pm 4.10^{\mathrm{a}}$ & $92.80 \pm 2.50^{\mathrm{a}}$ & $103.50 \pm 2.01^{\mathrm{a}}$ & 99.50 & 5.84 & 5.87 \\
\hline Ser & $31.90 \pm 0.21^{\mathrm{a}}$ & $21.50 \pm 0.32^{\mathrm{b}}$ & $32.90 \pm 0.21^{\mathrm{c}}$ & 28.77 & 6.31 & 21.95 \\
\hline Asp & $151.90 \pm 2.01^{\mathrm{a}}$ & $141.90 \pm 3.03^{b}$ & $170.10 \pm 2.00^{c}$ & 154.60 & 14.30 & 9.25 \\
\hline Pro & $29.80 \pm 0.13^{\mathrm{a}}$ & $17.00 \pm 0.21^{\mathrm{b}}$ & $32.90 \pm 0.80^{\mathrm{c}}$ & 26.57 & 8.43 & 31.73 \\
\hline Gly & $10.80 \pm 0.10^{\mathrm{a}}$ & $4.00 \pm 0.11^{\mathrm{b}}$ & $16.80 \pm 0.20^{\mathrm{c}}$ & 10.53 & 6.40 & 60.80 \\
\hline Ala & $52.50 \pm 0.30^{\mathrm{a}}$ & $37.10 \pm 0.39^{\mathrm{b}}$ & $56.30 \pm 0.61^{\mathrm{c}}$ & 48.63 & 10.17 & 20.91 \\
\hline Cys & $17.50 \pm 0.21^{\mathrm{a}}$ & $10.50 \pm 0.09^{b}$ & $24.00 \pm 0.19^{c}$ & 17.33 & 6.75 & 38.95 \\
\hline Tyr & $25.80 \pm 0.23^{\mathrm{a}}$ & $25.80 \pm 0.11^{\mathrm{b}}$ & $27.30 \pm 0.20^{\mathrm{c}}$ & 26.30 & 0.87 & 3.29 \\
\hline
\end{tabular}

Values (mean \pm standard of duplicate determinations) with different superscripts per row are significantly $(\mathrm{p}<0.05)$ different. SD, Standard deviation; CV\%, coefficient of variation percentage

Tables 3 and 4 show various calculated parameters aimed at providing data on protein quality of the seed samples. The total amino acids (TAA) content of raw seeds of $P$. africana and $R$. communis were improved by the fermentation process from $733.00 \mathrm{mg} / \mathrm{gcp}$ and 823.00 $\mathrm{mg} / \mathrm{gcp}$ to $962.60 \mathrm{mg} / \mathrm{gcp}$ and $894.10 \mathrm{mg} / \mathrm{gcp}$ respectively. These were close to or higher than those reported for fermented (708 mg/gcp) and unfermented (641 mg/gcp) cocoa nibs [27], $A$. occidentale (659 mg/gcp) [23] and dehulled samples of African yam bean (703-917 mg/gcp) [29]. The total non-essential amino acids (TNEAA) for the seed samples (mg/gcp) were: 422.00 (raw) and 558.10 (fermented) for P. africana (Table 3), and 422.40 (raw) and 463.80 (fermented) for $R$. communis (Table 4). The TNEAA values obtained were close to the value of 341-421 $\mathrm{mg} / \mathrm{gcp}$ in processed and unprocessed cocoa nibs [27], 327-454 mg/gcp in Africa yam bean [29] and 337.6-356.2 $\mathrm{mg} / \mathrm{gcp}$ in male fresh water crab [30]. The total essential amino acid (TEAA) compositions in $\mathrm{mg} / \mathrm{gcp}$ of the raw and fermented seed samples of $P$. africana were 311.00 and 404.50, while those of $R$. communis were 401.10 and 430.30 respectively. 
Table 3: Concentrations of essential, non-essential, acidic, basic, neutral, sulphur and aromatic amino acids (mg/g crude protein) of raw, boiled and fermented seed samples of Prosopis africana

\begin{tabular}{lllllll}
\hline Amino acid groupings & Raw & Boiled & Fermen & Mean & SD & CV\% \\
& & & & & & \\
\hline Total amino acid (TAA) & 733.00 & 637.40 & 962.60 & 777.70 & 167.10 & 21.49 \\
Total non-essential amino acid & 422.00 & 370.70 & 558.10 & 450.30 & 96.84 & 21.51 \\
(TNEAA) & & & & & & \\
Total essential amino acid (TEAA) & & & & & & \\
$\quad$ with His & 311.00 & 266.70 & 404.50 & 327.40 & 70.35 & 21.49 \\
$\quad$ without His & 294.70 & 254.80 & 379.50 & 309.70 & 63.68 & 20.57 \\
\% TNEAA & 57.57 & 58.16 & 57.98 & 57.90 & 0.30 & 0.52 \\
\% TEAA & & & & & & \\
$\quad$ with His & 42.43 & 41.84 & 42.02 & 42.10 & 0.30 & 0.72 \\
$\quad$ without His & 40.20 & 39.97 & 39.42 & 39.86 & 0.40 & 1.01 \\
Total neutral amino acid (TNAA) & 435.10 & 378.20 & 577.40 & 463.60 & 102.60 & 22.13 \\
\% TNAA & 59.36 & 59.33 & 59.98 & 59.56 & 0.37 & 0.62 \\
Total acidic amino acid (TAAA) & 199.40 & 182.70 & 264.00 & 215.40 & 42.94 & 19.94 \\
\% TAAA & 27.20 & 28.66 & 27.43 & 27.76 & 0.79 & 2.83 \\
Total basic amino acid (TBAA) & 98.50 & 76.50 & 121.20 & 98.73 & 22.35 & 22.64 \\
\% TBAA & 13.44 & 12.00 & 12.59 & 12.68 & 0.72 & 5.71 \\
Total sulphur amino acid (TSAA) & 31.60 & 24.70 & 55.00 & 37.10 & 15.88 & 42.81 \\
\% TSAA & 4.31 & 3.88 & 5.71 & 4.63 & 0.96 & 20.65 \\
\% Cys in TSAA & 67.09 & 83.00 & 76.18 & 75.42 & 7.98 & 10.58 \\
Total aromatic amino acid (TArAA) & 75.00 & 72.80 & 107.80 & 85.20 & 19.60 & 23.01 \\
\% TArAA & 10.23 & 11.42 & 11.20 & 10.95 & 0.63 & 5.78 \\
P-PER & 24.54 & 23.57 & 31.36 & 26.49 & 4.25 & 16.03 \\
Leu/Ile ratio & 1.91 & 2.40 & 1.87 & 2.06 & 0.30 & 14.33 \\
Leu - Ile & 30.00 & 35.20 & 36.90 & 34.03 & 3.60 & 10.56 \\
\% Leu - Ile & 4.09 & 5.52 & 3.83 & 4.48 & 0.91 & 20.31 \\
\hline
\end{tabular}

$\mathrm{SD}$, Standard deviation; CV\%, coefficient of variation percentage

These were higher than $300 \mathrm{mg} / \mathrm{gcp}$ and $287 \mathrm{mg} / \mathrm{gcp}$ reported for unfermented and fermented cocoa nibs [27], and 298.2-327.8 mg/gcp of male fresh water crab [30]. In comparison with other common seeds, the TEAA we obtained, were lower than the levels (mg/gcp) in melon (534) and gourd oilseed (536) [22], and close to those of pigeon pea (452) [31], soybean (444) [32], cowpea (426) [33], and Cajanus cajan (436) [34]. The percent TNEAA ranged between 57.57\% (raw) and $57.98 \%$ (fermented) for P. africana (Table 3); in R. communis (Table 4), it ranged from $51.29 \%$ (raw) to $51.87 \%$ (fermented); each with low CV\% values of 0.52 and 0.92 respectively. The \%TEAA (with His) ranged between $42.43 \%$ (raw) and $42.02 \%$ (fermented) in $P$. africana (Table 3), and between $48.71 \%$ (raw) and $48.13 \%$ (fermented) in $R$. communis (Table 4) with low CV\% values of 0.72 and 0.98 respectively.

These results showed that the TNEAA and TEAA values of $P$. africana and $R$. communis were very close, and that fermentation did not alter so much, the overall seeds' percentage contents of TNEAA and TEAA, notwithstanding the observed individual increases in total 
essential and non-essential amino acids composition after fermentation (Tables 1 and 2). The total neutral amino acids (TNAA) levels of the raw seeds of both plants were approximately the same $(435 \mathrm{mg} / \mathrm{gcp})$. However, fermentation increased the TNAA level of $P$. africana (577.4 $\mathrm{mg} / \mathrm{gcp})$ more than that of $R$. communis $(467.7 \mathrm{mg} / \mathrm{gcp})$.

Table 4: Concentrations of essential, non-essential, acidic, basic, neutral, sulphur and aromatic amino acids (mg/g crude protein) of raw, boiled and fermented seed samples of Ricinus communis

\begin{tabular}{lllllll}
\hline Amino acid groupings & Raw & Boiled & Fermented & Mean & SD & CV\% \\
\hline Total amino acid (TAA) & 823.50 & 688.40 & 894.10 & 802.00 & 104.50 & 13.03 \\
Total non-essential amino acid & 422.40 & 350.60 & 463.80 & 412.30 & 57.28 & 13.89 \\
(TNEAA) & & & & & & \\
Total essential amino acid (TEAA) & & & & & & \\
$\quad$ with His & 401.10 & 337.80 & 430.30 & 389.70 & 47.29 & 12.13 \\
without His & 384.20 & 324.70 & 409.00 & 372.60 & 43.32 & 11.63 \\
\% TNEAA & 51.29 & 50.93 & 51.87 & 51.36 & 0.47 & 0.92 \\
\% TEAA & & & & & & \\
with His & 48.71 & 49.07 & 48.13 & 48.64 & 0.47 & 0.98 \\
without His & 46.65 & 47.17 & 45.74 & 46.52 & 0.72 & 1.56 \\
Total neutral amino acid (TNAA) & 435.70 & 346.10 & 467.70 & 416.50 & 63.03 & 15.13 \\
\% TNAA & 52.91 & 50.28 & 52.31 & 51.83 & 1.38 & 2.66 \\
Total acidic amino acid (TAAA) & 254.10 & 234.70 & 273.60 & 254.10 & 19.45 & 7.65 \\
\% TAAA & 30.86 & 34.09 & 30.60 & 31.85 & 1.94 & 6.10 \\
Total basic amino acid (TBAA) & 133.70 & 107.60 & 152.80 & 131.40 & 22.69 & 17.27 \\
$\quad \%$ TBAA & 16.24 & 15.63 & 17.09 & 16.32 & 0.73 & 4.49 \\
Total sulphur amino acid (TSAA) & 45.10 & 33.90 & 53.00 & 44.00 & 9.60 & 21.81 \\
\% TSAA & 5.48 & 4.92 & 5.93 & 5.44 & 0.51 & 9.30 \\
\% Cys in TSAA & 38.80 & 30.97 & 42.28 & 37.35 & 5.79 & 15.51 \\
Total aromatic amino acid (TArAA) & 78.20 & 69.20 & 83.00 & 76.80 & 7.01 & 9.12 \\
\% TArAA & 9.50 & 10.05 & 9.28 & 9.61 & 0.40 & 4.13 \\
P-PER & 26.11 & 24.06 & 26.86 & 25.68 & 1.45 & 5.64 \\
Leu/Ile ratio & 1.74 & 2.27 & 1.75 & 1.92 & 0.30 & 15.79 \\
Leu - Ile & 27.50 & 33.60 & 28.50 & 29.87 & 3.27 & 10.95 \\
\% Leu - Ile & 3.34 & 4.88 & 3.19 & 3.80 & 0.94 & 24.60 \\
\hline
\end{tabular}

$\mathrm{SD}$, Standard deviation; $\mathrm{CV} \%$, coefficient of variation percentage

Many plant proteins, especially the legumes, contain substantially more Cys than Met [24]. This assertion agrees with our observation in $P$. africana in which total sulphur amino acid (TSAA) for the raw and fermented seed samples were 31.60 and $55.0 \mathrm{mg} / \mathrm{gcp}$, with the percentage of Cys in the TSAA (\%Cys/TSAA) being $67.09 \%$ and $76.18 \%$ respectively. However, the \%Cys/TSAA in raw and fermented $R$. communis samples were low at $38.80 \%$ and $42.20 \%$ respectively. Thus, while the \%Cys/TSAA of $P$. africana followed the pattern of $62.9 \%$ in coconut endosperm [35], and 58.9\% (raw), 72.0\% (steeped) and 71.1\% (germinated) guinea corn [28], those of $R$. communis followed the trend in C. acuminate (44.3\%) [23], G. kola $(37.8 \%)$, and fermented $(46.3 \%)$ and unfermented $(44.1 \%)$ cocoa nibs [27], as well as animal 
proteins; Macrotermes bellicosus (36.3\%) [36], Archatina archatina (38.8\%) and Archachatina marginata (35.5\%) [37]. Thus, our result of \%Cys/TSAA in $P$. africana corroborated the statement that Cys may supply up to one-third of the need for TSAA [13].

Muller and Tobin [21] reported that experimentally determined protein efficiency ratio (PER) usually ranged from 0.0 for a very poor protein to a maximum of just over 4 . Our results of predicted PER (P-PER) showed that fermented samples of $P$. africana (2.72) and $R$. communis (2.26) would likely be utilized more in the body than those of raw (2.03 and 2.19) or boiled (1.94 and 1.99) samples respectively. The P-PER results of the fermented samples compared flavourably with those of processed common legumes $(2.15-2.95)$, fermented cocoa nibs (2.55), and male fresh water crab $(2.70)[24,27,30]$.

The Leu/Ile ratios of the raw, boiled and fermented samples were 1.91, 2.40 and 1.87 $\mathrm{mg} / \mathrm{gcp}$ for $P$. africana, and $1.74,2.27$ and $1.75 \mathrm{mg} / \mathrm{gcp}$ for $R$. communis respectively. The increase in Leu/Ile ratio we observed after boiling is a consequence of the significant $(\mathrm{p}<0.05)$ decrease in Ile contents (see Tables 1 and 2) of both seed samples, instead of an increase in Leu content. Meanwhile, high Leu content in diet impairs tryptophan and niacin metabolism, might be a factor in pellagra development, and niacin deficiency in sorghum consumers $[38,39]$. Thus, it was suggested that Leu/Ile balance is a more important factor than dietary excess of Leu alone in regulating the metabolism of Trp and niacin, and hence the disease process [27]. Furthermore, it has been reported that animals fed sorghum proteins containing less than $110 \mathrm{mg} / \mathrm{gcp}$ of Leu did not suffer from nicotinic acid deficiency [40]. Interestingly, none of the plants' samples we studied had Leu levels up to this critical level.

Tables 5 and 6 show the amino acid scores (AAS), based on the provisional amino acids, for the samples of P. africana and R. communis respectively. In Table 5, Thr was the limiting amino acid for raw (0.62), boiled (0.54) and fermented (0.69) samples of $P$. africana.

Table 5: Essential amino acid scores of raw, boiled and fermented seed samples of Prosopis Africana

\begin{tabular}{lllllll}
\hline Amino acid & Raw & Boiled & Fermented & Mean & SD & CV\% \\
\hline Ile & 0.82 & 0.63 & 1.07 & 0.84 & 0.22 & 26.27 \\
Leu & 0.90 & 0.86 & 1.14 & 0.97 & 0.15 & 15.67 \\
Lys & 0.74 & 0.63 & 0.86 & 0.74 & 0.12 & 15.48 \\
Met + Cys & 0.90 & 0.71 & 1.57 & 1.06 & 0.45 & 42.62 \\
Phe + Tyr & 1.25 & 1.21 & 1.80 & 1.42 & 0.33 & 23.22 \\
Thr & 0.62 & 0.54 & 0.69 & 0.62 & 0.08 & 12.17 \\
Try & - & - & - & - & - & - \\
Val & 0.81 & 0.76 & 1.06 & 0.88 & 0.16 & 18.33 \\
\hline
\end{tabular}

$\mathrm{SD}$, Standard deviation; $\mathrm{CV} \%$, coefficient of variation percentage

These observations are in agreement with a previous report of Thr at an AAS of 0.55 being the limiting amino acid in raw seeds of $P$. africana [5]. To fulfill the day's need for all the EAA using $P$. africana seeds, $100 / 62$ or 1.61 times as much raw seed protein, 100/54 or 1.85 times as much boiled seed protein and 100/69 or 1.45 times of fermented seed protein, would have to be eaten when they are the sole protein in the diet. 
Table 6: Essential amino acid scores of raw, boiled and fermented seed samples of Ricinus communis

\begin{tabular}{lllllll}
\hline Amino acid & Raw & Boiled & Fermented & Mean & SD & CV\% \\
\hline Ile & 0.93 & 0.66 & 0.95 & 0.84 & 0.16 & 19.13 \\
Leu & 0.92 & 0.86 & 0.95 & 0.91 & 0.05 & 5.04 \\
Lys & 0.80 & 0.75 & 0.96 & 0.84 & 0.11 & 13.11 \\
Met + Cys & 1.29 & 0.97 & 1.51 & 1.26 & 0.27 & 21.61 \\
Phe + Tyr & 1.30 & 1.15 & 1.38 & 1.28 & 0.12 & 9.15 \\
Thr & 0.93 & 0.91 & 0.96 & 0.93 & 0.03 & 2.70 \\
Try & - & - & - & - & - & - \\
Val & 0.97 & 0.81 & 1.00 & 0.93 & 0.10 & 11.02 \\
\hline
\end{tabular}

$\mathrm{SD}$, Standard deviation; CV\%, coefficient of variation percentage

In Table 6, Lys was the limiting amino acid in raw seeds (0.80), and Ile or Leu in fermented seeds $(0.95)$ of $R$. communis. Their correction values would be 1.25 times the protein in raw seeds and 1.05 times in fermented seeds. The entire CV\% for the samples of both $P$. africana (Table 5) and $R$. communis (Table 6) were generally low.

\section{CONLUSION:}

$P$. africana and $R$. communis are good sources of protein and contain both essential and nonessential amino acids in quantities comparable with some animal proteins and other common legumes. While fermentation elicited about $31 \%$ and $9 \%$ overall positive buildup in total amino acid content in $P$. africana and $R$. communis, boiling caused $13 \%$ and $16 \%$ destruction of amino acids in the seeds. Thus, they can serve well in complementing weaning food for children in the tropics where protein malnutrition is one of the major causes of child morbidity and mortality.

Author's disclosure statement: We wish to confirm that no competing financial or nonfinancial interests exist between the Authors and any other people or institution.

Contribution of Individual Authors: CUI - Designed the research work and wrote up the manuscript. OAO - Partook in the research work and edited the manuscript. KCA - Initiated and sponsored the research work. LAN - Analyzed the data and edited the manuscript. COU Carried out the laboratory analyses and edited the manuscript.

\section{REFERENCES:}

1. Block RE, Morris SS, Bryce J: Where and why are 10 million children dying every year. Lancet 2003, 361: 2226-2234.

2. Muller O, Krawinkel M: Malnutrition and Health in developing countries. CMAJ 2005, 173(3): 279-284. 
3. Oshodi AA: Proximate composition, nutritionally valuable minerals and functional properties of Adenous breviflorus benth seed flour and protein concentrate. Food Chem 1992, 45: 7983.

4. Ojiako OA, Igwe CU, Agha NC, Ogbuji CA, Onwuliri,VA: Protein and Amino acid compositions of Sphenostylis stenocarpa, Sesanum indicum, Monodora myristica and Afzelia Africana seeds from Nigeria. Pakistan J Nutr 2010, 9(4): 368-372.

5. Aremu MO, Olonisakin A, Atolaye BO, Ogbu CF: Some nutritional and functional studies of Prosopis africana. Electronic J Environ Agric Food Chem 2006, 5(6): 1640-1648.

6. Lewis WH, Elvin-Lewis MPF: Medical botany: Plant affecting man's health. New York: John Wiley and Sons; 1977

7. Wedin GP, Neal J, Everson GW, Krenzelok EP: Castor beans poisoning. J Emerg Med. 1986, 4(3): 459-461.

8. Odunfa SA: African fermented foods. In : Fermented foods. 2nd ed. New York: BJB; 1985.

9. Achinewhu SC: Chemical and nutrient composition of fermented products from plant food. Nigerian Food Sc J 1983, 1: 115-117.

10. Onwuliri VA, Attah I, Nwankwo JO: Anti-nutritional factors, essential and non-essential fatty acids composition of ugba (Pentaclethra macrophylla) seeds at different stages of processing and fermentation. J Biol Scs 2004, 4(5): 671-675.

11. Pearson D: The chemical analysis of foods. 7th ed. London: Churchill Livingstone; 1976.

12. FAO/WHO: Energy and protein requirements. Technical Report Series No. 52. Switzerland, Geneva: WHO; 1973.

13. Alsmeyer RH, Cunningham AE, Happich ML: Equations to predict PER for amino acid analysis. Food Technol 1974, 28, 34-38.

14. Sanders DH: Statistics: A Fresh Approach (4th ed). Singapore: McGraw Hill Inc; 1990.

15. Balogun AM, Fetuga BL: Chemical composition of some under-exploited crops seeds of Nigeria. J Agric Food Chem 1986, 34: 189-192.

16. Harnold L M: Castor bean. An oil crop for mechanical production. Agronomy 2002, 10: 258266.

17. Fagbemi TN, Oshodi AA: Chemical composition and functional properties of full fat fluted pumpkin seed flour. Nig Food J 1991, 9: 26-32.

18. Odoemelam SA: Proximate composition and selected physico-chemical properties of the seeds of African oil bean (Pentaclethra macrophylla). Pakistan J Nutr 2005, 4: 382-383.

19. Ojiako OA, Igwe CU: The nutritive, anti-nutritive and hepatotoxic properties of Trichosanthes anguina (Snake tomato) fruits from Nigeria. Pakistan J Nutr 2008, 7(1):85-89.

20. Muller HE, Tobin G: Nutrition and food processing. London: Crown Helm; 1980.

21. Olaofe O, Adeyemi FO, Adediran GO: Amino acid and mineral compositions and functional properties of some oil seeds. J Agric Food Chem 1994, 42: 878-881.

22. Adeyeye EI, Asaolu SS, Aluko AO: Amino acid composition of two masticatory nuts (Cola acuminate and Garcinia kola) and a snack nut (Anacardium occidentale). Int J Food Scs Nutr 2007, 58(4): 241-249.

23. White A, Handler P, Smith EL: Principles of Biochemistry (5th ed.). New York: McGrawHill Inc. 1973. 
24. Khattab RY, Arntfield SD, Nyachoti CM: Nutritional quality of legume seeds as affected by some physical treatments, Part 1: Protein quality evaluation. LWT - Food Science and Technology 2009, 42(6): 1107-1112.

25. Ojiako AO, Anugweje K, Igwe CU, Alisi CS: Evaluation of the amino acid profile and haemoglobin polymerization inhibition potential of some Nigerian legumes. British Journal of Pharmaceutical Research 2012, 2(2): 80-88.

26. Adeyeye EI, Akinyeye RO, Ogunlade I, Olaofe O, Boluwade JO: Effect of farm and industrial processing on the amino acid profile of cocoa beans. Food Chemistry 2010, 118 (2010) 357-363.

27. Adeyeye EI: The intercorrelation of the amino acid quality between raw, steeped and germinated guinea corn (Sorghum bicolor) grains. Bull Chem Society Ethiopia 2008, 22(1): 11-17.

28. Adeyeye EI: Amino acid composition of six varieties of dehulled African yam bean (Sphenostylis stenocarpa) flour. Int J Food Scs Nutr 1997, 48: 345-351.

29. Adeyeye EI, Kenni AM: The Relationship in the Amino Acid of the Whole Body, Flesh and Exoskeleton of Common West African Fresh Water Male Crab Sudananautes africanus africanus. Pakistan J Nutr 2008, 7(6): 748-752.

30. Nwokolo E: Nutritional evaluation of pigeon pea meal. Plant Foods Hum Nutr, 1987 37: $283-$ 290.

31. Kuri YE, Sundar RK, Kahuwi C, Jones GP, Rivett DE: Chemical composition of Monerdica charantis L. fruits. J Agric Food Chem 1991, 39: 1702-1703.

32. Olaofe O, Umar YO, Adediran GO: The effect of nematicides on the nutritive value and functional properties of cowpea seeds (Vigna unguicalata L. walp). Food Chem 1993, 46(4): 337-342.

33. Oshodi AA, Olaofe O, Hall GM: Amino acid, fatty acid and mineral composition of pigeon pea (Cajanus cajan). Int J Food Scs Nutr 1992, 42: 187-191.

34. Adeyeye EI: The chemical composition of liquid and solid endosperm of ripe coconut. Oriental J Chem 2004, 20(3): 471-476.

35. Adeyeye EI: The composition of the winged termites, Macrotermes bellicosus. J Chem Society Nigeria 2005, 30(2): 145-149.

36. Adeyeye EI, Afolabi EO: Amino acid composition of three types of land snails consumed in Nigeria. Food Chem 2004, 85: 535-539.

37. Belavady B, Srikantia SG, Gopalan C: The effect of oral administration of leucine on the metabolism of tryptophan. Biochem J 1963, 87: 652-655.

38. FAO: Sorghum and millets in human nutrition. FAO Food Nutrition Series, No. 27. Rome, Italy: Food and Agriculture Organisation of the United Nations; 1995.

39. Belavady B, Udayasekhara Rao P: Leucine and isoleucine content of Jowar and its pellagragenicity. Indian J Exp Biol 1979, 17; 659-661. 